\title{
Decentralization System And Application Of Smart City Concept In Increasing Level Of Competitiveness And Ease Of Doing Business In Indonesian Urban Area
}

\author{
Delly Maulana ${ }^{1}$, Sukendar $^{2}$ \\ \{delly_maulana@yahoo.com ${ }^{1}$, kendar73@yahoo.com² ${ }^{2}$ \\ ${ }^{1,2}$ Department of Public Administration, Faculty of Social and Political Sciences, \\ Universitas Serang Raya, Banten, Indonesia
}

\begin{abstract}
Indonesia is one of countries implement decentralized system to regulate its governance system. Each region is required to be self-reliant and able to overcome problems faced by the region, including problems in increasing the value of regional competitiveness. This means that local authorities must be creative and innovative to provide society needs. However, low level of Global Competitiveness Index and Ease of Doing Business indicates that regional competitiveness of the urban area need to be improved. To improve the regional competitiveness, the adaption of concept of smart city for Indonesian urban area is considered. This paper is meant to relate the decentralization system with the concept of smart city model in achieving sustainable development and improving the quality of life of its citizens. Qualitative method with secondary data was used in this work. Significant improvement was found in several cities in Europe and Asia. Therefore adaptation of this concept to cities in Indonesia is very encouraged since it offers better solution to the improvement of the local government services. This indicates that role of society, city leaders and partnership between the private sector, government, and campus to actively initiate transformation of their city to be a smart city is important.
\end{abstract}

Keywords: Decentralization, Smart city, Competitiveness, Doing Business.

\section{Introduction}

Indonesia is one of countries that practice decentralized system to regulate its governance system. This system was adapted since 2009 after the falling of President Soeharto in 1998. In this system, each region required to be self-reliant and able to overcome some problems faced by the region, including problems in increasing the value of regional competitiveness. In addition, local governments must be able to make the region as a conducive area in investing and conducting business activities, so that conditions can contribute significantly the improvement global competitiveness to national development, both are at the world level, Asia, and ASEAN.

However, in the context of global competitiveness, Indonesia is still considered low compared to other ASEAN countries. The Global Competitiveness Index (GCI) report in 2014-2015 has ranked Indonesia in the rank of 34 (4.57), while other ASEAN countries, such as Malaysia was at the rank of 20 (5.16), Thailand ranked as 31 (4.66), and Singapore in rank 2 (5.65), respectively (Schwab et al., 2014: 13). Indonesia's GCI rank however decline in 2017-2018, which place Indonesia in the rank of 36 out of 137 countries (Schwab, 2017).

As a factor of determination of global competitive index, ability of a country in business also important. The Ease of Doing Business (EDB) report in 2015 shows thathas placed 
Indonesia in rank 114 (59.15) out of 137 countries. There was quite wide gap of rank between Indonesia to other ASEAN countries such Malaysia, Thailand and Singapore. Malaysia was ranked at number 18 (78.83), while Thailand ranked at 26 (75.27), and Singapore was ranked as the first (88.27) (World Bank, 2014: 4). It was reported that corruption, inefficient government bureaucracy, and access to financing as three most problematic factor for doing business in Indonesia (Schwab, 2017). This indicates that implementation of decentralization system in Indonesia currently failed to achieve its purpose.

In supporting the decentralization system practice, concept of smart city has been introduced in Indonesia. It was expected that interaction between information and communication technology (ICT) infrastructure to human and social capital can address public issues, achieve sustainable development and improve the quality of life of its citizens. The concept smart city is considered able to improve GCI and EDB of Indonesian urban area by increasing innovation and creativity to support business development in urban area which covers $19.1 \%$ of total Indonesia area(Kemendagri, 2014). It is believed that in future, the urban area will grow continuously in line with the influence of social, economic, political, and cultural development. Therefore this paper is meant to relate the decentralization system with the concept of smart city model in achieving sustainable development and improving the quality of life of its citizens

\section{Decentralization, The Spirit Of Innovation, And Creativity Of Local Governments}

Decentralization system basically meant to accelerate the pace and spread the benefits of growth and use scarce resources more efficiently to promote development in poverty stricken or economically lagging areas. In Indonesia, decentralization system generally practice the transfer of authority and responsibility from central government to the lower levels of government or to private sector (Cheema and Rondinelli, 2007).

Based on the form of authority being delegated, Decentralization can be categorized into four general forms i.e. : (i) administrative decentralization which relate to redistribution of authority, responsibility, and financial resources from the central government to the local government, (ii) fiscal decentralization which relate to ways and mechanisms of revenue sharing and expenditure allocation; and for fiscal authority for central and local or local government, (iii) political decentralization which relate to organizations and procedures for creating public participation in elections and constructing public policy and (iv) economic desentralization which includes market liberalization, deregulation, privatization of stateowned enterprises (SOE), public and private partnerships. This is a shift of responsibility function to a society that was once owned or monopolized by the government, but now it can be done by the private sector, and non-governmental organizations (Rondinelli, 1981); (Darmawan, 2008).

The implementation of administrative and fiscal decentralization is believed will create good governance in Indonesia. According to Grindle (Darmawan, 2008), decentralization can improve the basic principles of good governance that include political openness, participation, tolerance, administration and bureaucratic capacity and efficiency. It can also be seen as a way of enhancing the capacity of local governments by providing modernization in the public sector. Implementation of political decentralization is seen as a way of improving political representation in political, ethnic, religious, and cultural groups without undermining the stability of a country. It can thus be seen as a way to increase community participation in the development process and to bring public policy-making processes closer to the community. 
This condition is the most important thing, especially for countries that have cultural, religious, and tribal diversity.

Implementation of fiscal and economic decentralization can also increase the creativity and innovation of local governments in responding to the needs of the community through the concept of entrepreneurship. These conditions can improve regional development equity, empower communities, and mobilize private resources to invest in infrastructure and public facilities. The ecomnomic desentralization is also believed able to provide a resource allocation that is beneficial to the community. Allocation of efficiency is a condition where limited resources in the public sector are allocated to the wishes of the community that can bring maximum benefits.

Therefore, implementation of decentralization concept in Indonesia both theoretically and practically should be able to drive spirit of creativity, innovation, and competitiveness of local governments in responding the needs of society through the concept of entrepreneurship. This also in accordance with law number 23 of 2014 about local government. According to law number 23 of 2014, the local government is enforce to accelerate the realization of community welfare through service improvement, empowerment, community participation, and enhancement of regional competitiveness with regards to the principles of democracy, equity, justice, and uniqueness of a region.

\section{Research Methodology}

The method that used in this research is qualitative research method by using secondary data.

\section{Result And Discussion: Application Of Smart City Concept In Increasing Competitiveness And Easiness Of Business Of Urban Area}

Smart city is a city that connects ICT infrastructure with human and social capital to address public issues, achieve sustainable development and improve the quality of life of its citizens. The purpose of applying the concept of smart city has 3 (three) objectives, namely: (i) achieving sustainable development; (ii) .improving the quality of life of its citizens; and (iii) improving the efficiency of existing and new infrastructure. Smart city development is linking between environment, social and economy with smart application so as to produce liveable, equitable, and economic with technological, human and institutional support as shown in Figure 1. There are three major actors in supporting the successfulness of this concept, namely: (i) Government and Authority or Authorized Officials; (ii) Public and private sector partnerships; and (iii) Community participation. This indicates that the objective of smart city application can be achieved if the local government utilize information and communication technology as a tool of improvement of the city. (European investment bank insitute).

There are six areas that can be developed with the implementation of smart city concept; i.e. (i) Smart Governance; (ii) Smart Economy; (iii) Smart Mobility; (iv) Smart Environment; (v) Smart people; and (vi) Smart Living. If these areas can be developed by concept of smart city, it is thought that it will increase the level of competitiveness and the level of ease of doing business in the respective urban area. 


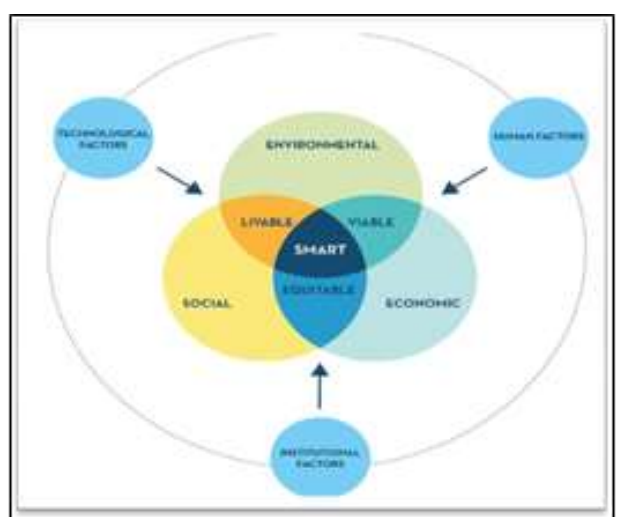

Fig.1. Smart City Development Model

Table 1. Smart City Action Fields and Areas

\begin{tabular}{|c|c|c|c|c|c|}
\hline \multicolumn{6}{|c|}{ SMART CITY ACTIONS FIELDS AND AREAS } \\
\hline $\begin{array}{l}\text { Sustainable } \\
\text { Aspects }\end{array}$ & City & City Areas & $\begin{array}{l}\text { Smart City } \\
\text { Fields }\end{array}$ & Action & Smart City Areas \\
\hline \multirow[t]{5}{*}{ Economic } & & \multirow[t]{5}{*}{ Institutions } & \multirow{3}{*}{\multicolumn{2}{|c|}{ Governance }} & Participation \\
\hline & & & & & Transparency \\
\hline & & & & & $\begin{array}{lll}\text { Public } & \text { And } & \text { Social } \\
\text { Services } & & \\
\end{array}$ \\
\hline & & & \multirow{2}{*}{\multicolumn{2}{|c|}{ Economy }} & Innovation \\
\hline & & & & & Entrepreneurship \\
\hline \multirow[t]{7}{*}{ Environmental } & & \multirow[t]{7}{*}{ Habitat } & \multirow{4}{*}{\multicolumn{2}{|c|}{ Mobility }} & Traffic \\
\hline & & & & & Public Transport \\
\hline & & & & & ICT Infrastructure \\
\hline & & & & & Logistics \\
\hline & & & \multirow{3}{*}{\multicolumn{2}{|c|}{ Environment }} & $\begin{array}{l}\text { Network } \\
\text { Environmental }\end{array}$ \\
\hline & & & & & Monitoring \\
\hline & & & & & Energy Efficiency \\
\hline \multirow[t]{5}{*}{ Social } & & \multirow[t]{5}{*}{ Citizen } & \multirow{2}{*}{\multicolumn{2}{|c|}{ People }} & Digital Education \\
\hline & & & & & Creativity \\
\hline & & & \multirow{3}{*}{\multicolumn{2}{|c|}{ Living }} & Tourism \& Culture \\
\hline & & & & & Health \& Safety \\
\hline & & & & & Technology Accessibility \\
\hline
\end{tabular}

In the field of local governance, the participation, transparency of the citizen will be increased if human and social capital can be easily connected with established ICT infrastructure thus improvement in public and social services also improved. In terms of economy, smart city concept can increase the spirit of innovation and entrepreneurship with good ICT infrastructure. Good ICT infrastructure can provide comfort and convenience for business people in doing business activities in the city as shown in Table 1.

Concept of smart city also can increase the level of regional competitiveness. Regional competitiveness can be increased if the area is institutionally creating good governance which 
indicates by such factor as increasing of public participation, transparency, and improvement of public services. This factor typically in associated with several indicators that measure the level of global competitiveness such as: the level of corruption, inefficient bureaucracy, inadequate infrastructure, political instability, access to financing, sufficiently educated labour, poor work ethic, government instability, inflation, taxation, tax rate, restrictive labour regulations, crime and theft, general health labour, foreign currency regulations. Thus if concept of smart city is successfully implemented, realization of good governance is believed can be happen thus increase the national competitiveness index.

The indicators of EDB utilized by the World Bank shows that the EDB of a nation will increase if the condition of the region, especially urban areas used as sample increase first. Several indicators of sustainability of EDB are: (i) minimum procedure, time, cost and capital to be deposited to start the business; (ii) Procedures, time and cost to complete all formalities to build a warehouse; (iii) Procedure, time and cost to be connected to the power grid; (iv) Procedure, time and cost to transfer property; (v) Movable legal guarantee and credit information system; (vi) The minority interest of shareholders in transactions with related parties; (vii) Payment, time and total tax rate for the company to comply with all tax regulations; (viii) Documents, time and cost for export and import by port institutions; (ix) Procedures, time and cost to resolve commercial disputes; and (x) Time, cost, yield and rate of recovery for commercial bankruptcy (World Bank, 2014 : 2). It is clear that application concept of smart city which subjected to improve entrepreneurship spirit, public services, energy efficiency, access technology, public transport, ICT Infrastructure, Traffic, creativity of the community and others is related to the indicators used in determine the EDB index. Furthermore, in the economic field, institutions must be able to create innovation and entrepreneurial spirit. This condition will also increase the level of regional competitiveness. Therefore, the conclusion is that the application of smart city may be able to give a significant impact in improving regional competitiveness, especially urban areas in Indonesia. Practically the concept of smart city has been applied in several cities in Europe. The smart city was launched in 2011 with the aim to forge partnerships between the industrial sector and cities in Europe (to develop future urban and infrastructure systems). The development of this concept has been carried out in UK cities, such as Birmingham, Bristol, Glasgow, London and Manchester. One of the most intense talks about smart city innovation centers is Bristol, the city council and university have teamed up to implement the project with a value of around $£$ 75 million in the city-wide for expansion of optic fiber infrastructure, coupled with creating a live lab for the development and testing of new products and services in the city (Joss, 2015 : 4-5). This program has also been launched in several countries in Asia such as China, India and South Korea. The concept is also supported by several international technology companies, such as: Cisco, Hitachi and IBM, both as contributors to conceptual development and partners in smart city pilot projects. (Joss, 2015 : 4). In Indonesia, the application of smart city concept has been implemented in several areas, such as DKI Jakarta, Bandung, Surabaya, Yogyakarta, Bogor, and Malang. Smart city application has been implemented since 2003 in Surabaya by applying e-government and e-procurement, while e-budgeting, e-delivery, econtrolling, and e-monitoring will be applied next. It was expectated that the situation in the cities practically can be monitored, ranging from road traffic till the condition of landfills by implementing the concept of e-monitoring in Surabaya (voaindonesia.com/a/kota-kota Indonesia to smart city / 302441 downloaded on December 1, 2015 at $15.30 \mathrm{wib}$ )

Furthermore, the development of smart city in Surabaya City, the government collaborated with Surabaya Institute of Technology (ITS) as provider for application and internet networking that support smart city implementation in order to create effectiveness and 
efficiency of service (Novianti et al., 2017). Of course, this concept will not work optimally if it is not supported by the consistency role of the mayor leadership. Therefore, smart city implementation in several cities around the world including several city in Indonesia must be adapted by other cities since it offer better solution to the improvement of the local government services. This indicates that the role of the city leaders is a major factor in creating the effectiveness of the smart city concept. The partnership between the private sector, government, and campus also support the concept of smart city. Last but not the least, the role of society to actively initiate transformation of their city to be a smart city is highly important.

\section{Conclusions}

The problem of low competitiveness and doing business in urban area automatically reduce the level of global competitive index (GCI) of Indonesia. By utilizing decentralization and smart city system, it is expected that the spirit of local government participation can be enhanced thus innovation as well as creativity of people in responding to the needs of society through the concept of entrepreneurship can be developed. However, factor such as corruption and inefficient government bureaucracy, which should be reduced by decentralization and smart city system, are still consider as main reason to low doing business index. Therefore support by the local government, authorities or authorities of the local government, private sector, and public is very important to ensure good implementation of decentralization and smart city.

\section{References}

[1] Cheema, G. S. and Rondinelli, D. a. (2007) Decentralizing Governance: Emerging Concepts and Practices. doi: 10.1093/publius/pjn003.

[2] Darmawan, R. E. (2008) 'The practices of decentralization in Indonesia and its implication on local competitiveness', pp. 1-99.

[3] European investment bank insitute (no date) 'Smart cities : Concept, challenges and projects ascimer document'. European investment bank insitute, p. 31.

[4] Joss, S. (2015) 'SMART CITIES : FROM CONCEPT TO PRACTICE 1', (February), pp. 1-7.

[5] Kemendagri (2014) 'Daerah-Daerah Otonom Di Indonesia Sampai Dengan Tahun 2014'.

[6] Novianti, K. et al. (2017) 'CITY YANG DITERAPKAN DI JAKARTA DAN SURABAYA 1 TOWARDS SMART CITY: LESSONS FROM THE IMPLEMENTATION OF SMART CITY ' S CONCEPT IN JAKARTA AND SURABAYA Lembaga Ilmu Pengetahuan Indonesia, Jakarta', (April 2016), pp. 1-8.

[7] Rondinelli, D. A. (1981) 'Government Decentralization in Comparative Perspective: Theory and Practice in Developing Countries', International Review of Administrative Sciences, 47(2), pp. 133-145. doi: 10.1177/002085238004700205.

[8] Schwab, K. et al. (2014) The Global Competitiveness Report, World Economic Forum Reports 2014. doi: ISBN-13: 978-92-95044-73-9.

[9] Schwab, K. (2017) The Global Competitiveness Report The Global Competitiveness Report 2017-2018, World Economic Forum. doi: 92-95044-35-5.

[10] World Bank (2014) Doing business 2015 Going Beyond Efficiency, World Bank. doi: 10.1596/978-1-4648-0351-2.

[11] voaindonesia.com/a/kota-kota Indonesia mеnиju smart city/302441 downloaded on December 1, 2015 at 15.30 wib. 